九州大学学術情報リポジトリ

Kyushu University Institutional Repository

The Vegetable Leafminer Liriomyza sativae Blanchard (Diptera:Agromyzidae) and its Parasitoids on Cucumber in the Hochiminh Region of Vietnam

Tran, Thi Thien

Department of Plant Protection, Faculty of Agriculture, Nong Lam University

Tran, Dang Hoa

Laboratory of Insect Natural Enemies, Division of Biological Control, Department of Applied Genetics and Pest Management, Graduate School of Bioresource and Bioenvironmental

Sciences, Kyushu University

Konishi, Kazuhiko

Entomology Laboratory, National Agricultural Research Center for Hokkaido Region

Takagi, Masami

https://doi.org/10.5109/4628

出版情報：九州大学大学院農学研究院紀要. 50 (1)，pp. 119-125，2005-02-01. Faculty of Agriculture, Kyushu University

バージョン :

権利関係 : 


\title{
The Vegetable Leafminer Liriomyza sativae Blanchard (Diptera: Agromyzidae) and its Parasitoids on Cucumber in the Hochiminh Region of Vietnam
}

\author{
Thi Thien An TRAN ${ }^{1}$, Dang Hoa TRAN ${ }^{2}$, Kazuhiko KONISHI ${ }^{3}$ \\ and Masami TAKAGI*
}

\author{
Laboratory of Insect Natural Enemies, Division of Biological Control, Department of \\ Applied Genetics and Pest Management, Faculty of Agriculture, \\ Kyushu University, Fukuoka 812-8581, Japan \\ (Received October 28, 2004 and accepted November 11, 2004)
}

\begin{abstract}
The vegetable leafminer Liriomyza sativae has been well established on many vegetable crops in Vietnam, but have never been investigated the leafminer relative abundance and its associated parasitoids. A survey was conducted in three locations of the Hochiminh region of Vietnam during the rainy and dry season (July 2003-January 2004) with arm at recording associated parasitoid species complex and relative abundance of the leafminer and its parasitoids on the cucumber fields. Infestations of $L$. sativae occurred in the field during the rainy season with low densities and became more serious in the dry season. Sampling of leafminer-infested leaves from cucumber plants yielded 7 species of hymenopteran parasitoids. The most abundant species were Neochrysocharis sp. and Asecodes delucchii, accounting for $43.7-69.6 \%$ and $18.5-46 \%$ parasitism, respectively. The pest population was low when parasitism was high in all fields sampled. The results suggest that these parasitoids play a very important role in $L$. sativae suppression in the cultivated cucumber fields.
\end{abstract}

\section{INTRODUCTION}

Among the polyphagous Liriomyza species, Liriomyza sativae (Blanchard), Liriomyza trifolii (Burgess) and Liriomyza huidobrensis (Blanchard) are economically important pests of a wide variety of vegetable and ornamental crops worldwide (Murphy and LaShalle, 1999). Native to the North America, L. sativae is widespread over many countries in the world (Spencer, 1973; Murphy and LaShalle, 1999). L. sativae was also dominant Liriomyza species found on various vegetables including tomato, watermelon, white gourd, Chinese mustard, French bean, yard-long bean and cucumber throughout most of Vietnam (Thang, 1999; Andersen et al., 2002).

Currently, conventional control of leafminers has been dependent on synthetic chemical insecticides, including chlorfenapyr, chlorfluazuron, chlorpyriphos-etyl, deltamethrin, diazinon, edosulfan, malathion, abamectin and cyromazine (Sivapragasam

1 Department of Plant Protection, Faculty of Agriculture, Nong Lam Univesrity, Hochiminh, Vietnam

2 Laboratory of Insect natural Enemies, Division of Biological Control, Department of Applied Genetics and Pest Management, Graduate School of Bioresource and Bioenvironmental Sciences, Kyushu University

3 Entomology Laboratory, National Agricultural Research Center for Hokkaido Region, Sapporo 062-8555, Japan

* Corresponding author (E-mail: mtakagi@agr.kyushu-u.ac.jp) 
and Syed, 1999; Thang, 1999; Civelek and Weintraub, 2003). However, applications of broad spectrum insecticides have resulted in a decline in parasitism and the development of resistance within fly population followed by an increase in leafminer density (Oatman and Kennedy, 1976; Murphy and LaSalle, 1999; Thang, 1999; Tran et al., 2004).

Agromyzid leafminers are known to have rich natural enemy communities. Over 40 species of parasitoids have been recovered from Liriomyza spp. leafminers in the world (Waterhouse and Norris, 1987). In Japan, Neochrysocharis formosa (Westwood), Hemiptarsenus varicornis (Girault), Neochrysocharis okazakii Kamijo and Chrysochasis pentheus (Walker) (Eulophidae) are numerically dominant species (Arakaki and Kinjo, 1998). Eleven species of parasitoids such as Chrysochasis pentheus (Walker), N. formosa, N. okazakii, Neochrysocharis sp., H. varicormis, Cirrospilus ambiguus Hansson \& LaSalle, Asecodes sp., Closterocerus sp., Quadrastichus sp. (Eulophidae), Ooencyrtris sp. (Eucyrtidae) and Gronotoma sp. (Eucolidae) have been reported in Vietnam (Thang, 1999). They have played a very important role in leafminer suppression in natural ecosystems or cultivated areas with reduced insecticide use (Johnson et al., 1980a).

The objectives of this study were to survey damage caused by L. sativae in three large cucumber-growing areas of the Hochiminh region of Vietnam; to determine associated parasitoid complex and relative abundance of the leafminer and its parasitoids.

\section{MATERIALS AND METHODS}

Surveys were carried out from July 2003 until January 2004 in the cultivated cucumber fields of three districts named Thuduc, Hocmon and Cuchi. In generally, the local cucumber varieties of Dualeotrang and Dualeoxanh were planted from July 2003, the middle of the rainy season, to January 2004, the middle of the dry season, using standard local practices, except that no pesticides were applied. Each district, five fields were monitored 1-3 times per month through the growing season by collecting 25 infested leaves at random. Leaves were placed in plastic bags labeled with the name of location and date. Samples were placed in an ice chest and brought into the laboratory and held in plastic containers $(15 \mathrm{~cm} \times 25 \mathrm{~cm})$ with $(8 \mathrm{~cm} \times 12 \mathrm{~cm})$ rectangular holes covering with fine mesh screen for air ventilation for emergence of leafminer and parasitoids. Numbers of $L$. sativae and parasitoids that emerged were counted and recorded daily. All flies and wasps were separately kept in small vials with $70 \%$ ethanol. Identification of parasitoids was done by the third author with help of Dr. Kazuaki Kamijo (Bibai, Hokkaido, Japan).

\section{RESULTS}

\section{Parasitoid species composition}

A total of 4,122 parasitoid individuals emerged from leafminer-infested cucumber leaves collected and 7 parasitoid species of 3 families (Braconidae, Eucoilidae and Eulophidae) were identified (Table 1). Among them, Neochrysocharis sp. was the most abundant species in both of rainy and dry seasons, accounting for $53.1-59.4 \%$ and $43.7-69.6 \%$, respectively. Asecodes delucchii was the second most abundant species in both of the rainy and dry seasons, accounting for $31.1-40.5 \%$ and $18.5-46 \%$, respectively 
Table 1. Species composition of parasitoids of $L$. sativae on cucumber in Hochiminh, Vietnam.

\begin{tabular}{ll}
\hline \multicolumn{1}{c}{ Family } & \multicolumn{1}{c}{ Species } \\
\hline Braconidae & 1. Opius sp. \\
Eucoilidae & 2. Gromotoma sp. \\
Eulophidae & 3. Cirrospilus ambiguus Hansson \& LaSalle \\
& 4. Neochrysocharis sp. \\
& 5. Asecodes delucchii (Boucek) \\
& 6. Diglyphus isaea (Walker) \\
& 7. Hemiptarsenus varicornis (Giraut) \\
\hline
\end{tabular}

Table 2. Number (emerged adult) and relative abundance (\%) of $L$. sativae parasitoids reared from cucumber leaves collected in the rainy and dry seasons in different districts of Hochiminh, Vietnam.

\begin{tabular}{lccc}
\hline Season and district & Neochrysocharis sp. & Asecodes delucchii & Others \\
\hline Rainy season ( from July 2003 to October 2003) & & \\
Thuduc & $451(59.4)$ & $236(31.1)$ & $72(9.5)$ \\
Hocmon & $665(56.7)$ & $475(40.5)$ & $33(2.8)$ \\
Cuchi & $750(53.1)$ & $492(34.8)$ & $171(12.1)$ \\
Dry season (from November 2003 to January 2004) & & \\
Thuduc & $173(43.9)$ & $106(33.9)$ & $69(22.1)$ \\
Hocmon & $296(69.6)$ & $79(18.5)$ & $50(11.8)$ \\
Cuchi* & - & - & - \\
\hline
\end{tabular}

* Crop finished

(Table 2).

\section{Seasonal occurrence of leafminer and parasitoids}

In three districts (Thuduc, Hocmon, Cuchi) of Hociminh city, densities of $L$. sativae were low during the rainy season. During this period, parasitism was very high and reached a peak of nearly 97,95 and $80 \%$ in Thuduc, Hocmon and Cuchi, respectively. Infestations of $L$. sativae became more serious in the dry season. The most severe was in the end of November 2003 when the densities reached a peak of nearly 38 larvae/ leaf in Thuduc and Hocmon. Parasitism in the dry season was declined and the pest completely destroyed the crop by the end of November 2003 in Hocmon, the beginning of January 2004 in Thuduc (Fig. 1).

\section{DISCUSSION}

Liriomyza sativae have been accidentally introduced into Vietnam. Currently, this has been well established in Vietnam on many vegetable crops (Andersen et al., 2002) and become one of the most important pests on cucumber (Rauf and Shepard, 1999). The occurrence and relative abundance of leafminers associated with season and host plants may reflect the impact of climate and their distinct preferences for host plants 

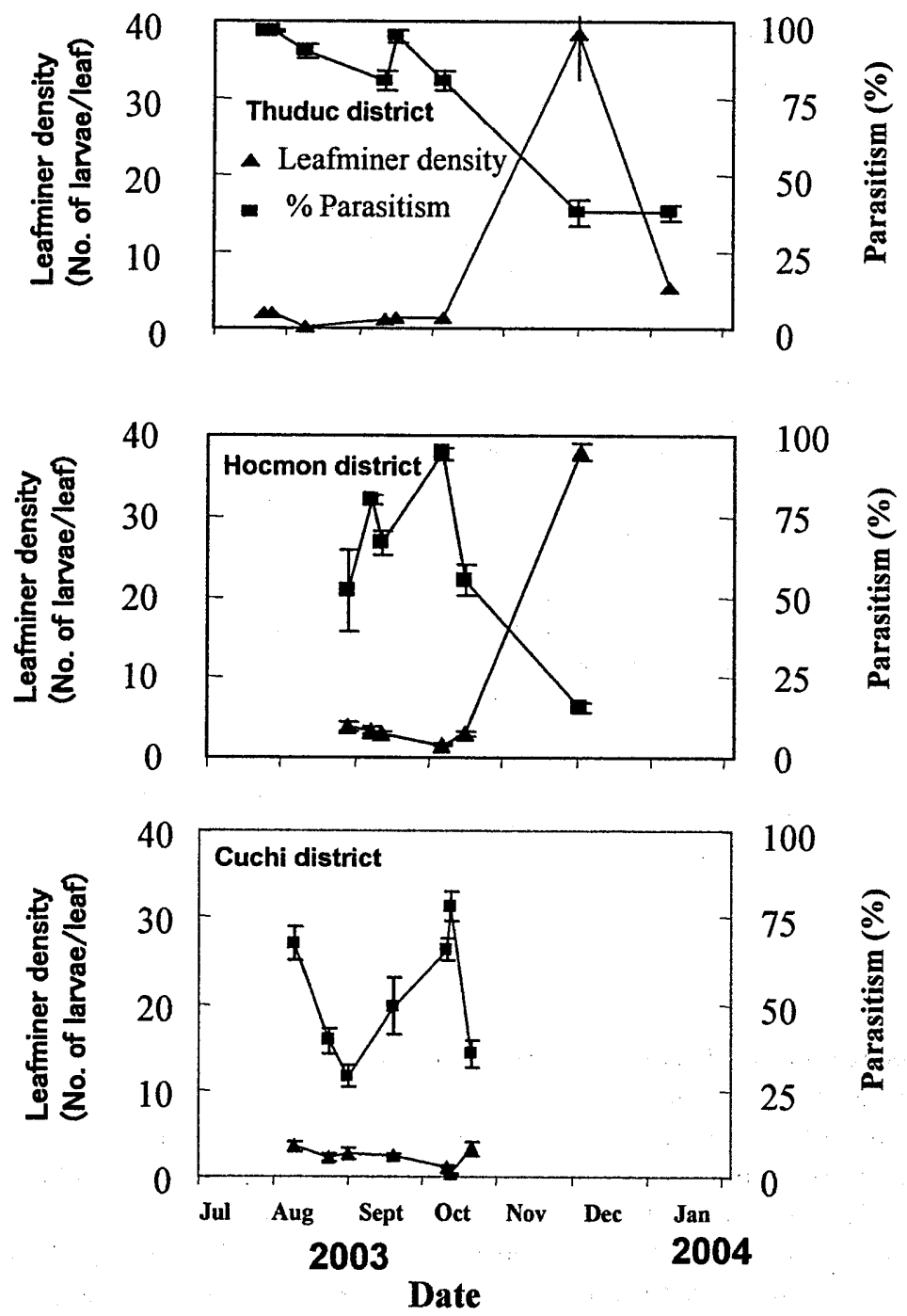

Fig. 1. Liriomyza sativae population density and its parasitism on cucumber in Hochiminh, Vietnam

(Parrella, 1987).

The impacts of $L$. sativae on cucumber plant growth and yields were not investigated in this study, but the plants were completely lost to the pest during the dry season. The densities of $L$. sativae larvae were low in the rainy season and increased in the dry season (Fig. 1). Previous survey on tomato in Indonesia have also shown that infestations of $L$. 
hudobrensis during the rainy season were generally low, and occurred in the end of the dry season (Rauf and Shepard, 1999). It was considered that the infestations were associated with crop phenology; populations of leafminers increased slowly during the vegetative growth and increased rapidly during the generative growth, followed by a decline as plants entered into senescence (Rauf and Shepard, 1999). In our survey, rate of parasitism decreased just before rapid increase of leafminer density in all of three districts (Fig. 1). This suggested that activity of the parasitoids was low caused high density of the leafminer in the dry season.

Waterhouse and Norris (1987) reported more than 40 parasitoid species of Liriomyza leafminers, but few of these species occur in the Pacific region. Our study confirms that the parasitoid complex on L. sativae on cucumber in the Hochiminh region of Vietnam is limited to 7 species found. Leafminer parasitoids are abundant in the Philippine highlands of the Cordilleras, with at least ten species recorded, including $A$. delucchii, N. formosa, N. okazakii and H. varicomis (Joshi, 2001). Ascodes delucchii is a Palaearctic parasitoid found recently in Southeast Asia (Joshi, 2001), and become second most abundant parasitoid species of $L$. sativae on cucumber in the Hochiminh region of Vietnam (Table 2). Shuster and Wharton (1993) reported that Diglypus intermadius, Diglypus begini, and Neochrysocharis punctiventis were the most abundant parasitoids reared from $L$. sativae and $L$. trifolii on tomato in Florida. Many studies have identified parasitoids of $L$. sativae (Jonhson et al., 1980b; Chandler, 1983; Parrella, 1987; LaShalle and Parrella, 1991; Chen et al., 2003), but parasitoid complex was different from each other. Even in the Oriental Region, any of ten species of $L$. sativae parasitoids recorded from Hangzhou, China by Chen et al. (2003) were not obtained in our survey. Petcharat et al. (2002) reported 6 parasitoids of Liriomyza spp. from Southern Thailand. Among them, 2 species, C. ambiguus and H. varicornis, were collected in our survey. Moreover, the dominant species were quite different from one another. Thus, it seems that component and dominant species of parasitoid complex of Liriomyza in the Oriental Region are variable. The importance of the parasitoidsl in controlling the leafminer population was not clear in this study, but the pest population was low when parasitism was high in all fields sampled (Fig. 1). The observation that Neochrysocharis sp. and $A$. delucchii could reach high rate of parasitism on $L$. sativae on cucumber in Hochiminh suggests that they could be considered as potential agents for biological control program.

\section{ACKNOWLEDGMENTS}

We thank Dr. A. Andersen, Department of Entomology and Nematology, The Norwegian Crop Research Institute and The Agricultural University of Norway for his identification of the leafminer. We also thank to Mrs. L. T. T. Lam for her assistance in the fields and the laboratory. We extend our thanks to our farmer cooperators for their assistance and collaboration on survey making in their fields.

\section{REFERENCES}

Andersen, A., E. Nordhus, V. T. Thang, T. T. T. An, H. Q. Hung and T. Hofsvang 2002 Polyphagous 
Liriomyza species (Diptera: Agromyzidae) in vegetables in Vietnam. Trop. Agric. (Trinidad), 79(4): 241-246

Arakaki, N. and K. Kinjo 1998 Notes on the parasitoid fauna of the serpentine leafminer Liriomyza trifolii (Burgess) (Diptera: Agromyzidae) in Okinawa, Southern Japan. Appl. Entomol. Zool., 33(4): $577-581$

Chandler, L. D. 1983 Parasites of Liriomyza sativae Blanchard on bell peppers in South Texas. J. Georgia Entomol. Soc., 19(2): 199-203

Chen, X. X., X. Y. Lang, Z., H. Xu, J. H. He and Y. Ma 2003 The occurrence of leafminers and their parasitoids on vegetables and weeds in Hangzhou area, Southeast China. Biocontrol, 48: 515-527

Civelek, H. S. and P. G. Weintraub 2003 Effects of bensultap on larval serpentine leafminers, Liriomyza trifolii (Burgess) (Diptera: Agromyzidae), in tomatoes. Crop Prot., 22: 479-483

Johnson, M. W., E. R. Oatman and J. A. Wyman 1980a Natural control of Liriomyza sativae (Dip.: Agromyzidae) in pole tomatoes in Southern California. Entomophaga, 25(2): 193-198

Johnson, M. W., E. R. Oatman and J. A. Wyman 1980b Effects of insecticides on population of the vegetable leafminer and associated parasitoids on fall pole potatoes. J. Econ. Entomol., 73: 61-71

Joshi, R. C. 2001 Phillippines home to leafminer parasitoids. Biocontrol News and Information, 22(3): $60 \mathrm{~N}$

LaShelle, J. and M. P. Parrella 1991 The Chalcidoid parasites (Hymenoptera: Chalcidoidae) of economically important Liriomyza species (Diptera: Agromyzidae) in North America. Proc. Entomol. Soc. Washington, 93(3): 571-591

Murphy, S. T. and J. LaSalle 1999 Balancing biological control strategies in the IPM of New World invasive Liriomyza leafminers in field vegetable crops. Biocontrol News and Information, 20(3): 91-104

Oatman, E. R. and G. G. Kennedy 1976 Methomyl induced outbreak of Liriomyza sativae on tomato. $J$. Econ. Entomol., 69: 667-668

Parrella, M. P. 1987 Biology of Liriomyza. Ann. Rev. Entomol., 32: 201-224

Petcharat, J., L. Zeng, W. Zhang, Z. Xu and Q. Wu 2002 Larval parasitoids of agromyzid leaf miner genus Liriomyza in the southern Thailand: species and their host plants. Songklanakarin J. Sci. Technol., 24(3): 467-472

Rauf, A. and B. M. Shepard 1999 Leafminers in vegetables in Indonesia: surveys of host crops, species composition, parasitoids and control practices. In "Proceedings of a Workshop on Leafminers of Vegetables in Southeast Asia", ed. by G. S. Lim, S. S. Soetikno and W. H. Loke, Serdang, Malaysia, CAB International, Southeast Asia Regional Centre, pp. 25-35

Schuster, D. J. and R. A. Wharton 1993 Hymenopterous parasitoids of leaf- mining Liriomysa spp. (Diptera: Agromyzidae) on tomato in Florida. Environ. Entomol., 22(5): 1188-1193

Sivapragasam, A. and A. R. Syed 1999 The problem and management of agromyzid leafminers on vegetables in Malaysia. In "Proceedings of a Workshop on Leafminers of Vegetables in Southeast Asia", ed. by G. S. Lim, S. S. Soetikno and W. H. Loke, Serdang, Malaysia, CAB International, Southeast Asia Regional Centre, pp. 36-41.

Spencer, K. A. 1973 Agromyzidae (Diptera) of economic importance. The Hague, Netherlands, Dr W. Junk, pp. 418

Thang, V. T. 1999 Surveys of leafminers (Liriomyza) and their parasitoids on vegetable in Vietnam 1998. In "Proceedings of a Workshop on Leafminers of Vegetables in Southeast Asia", ed. by G. S. Lim, S. S. Soetikno and W. H. Loke, Malaysia, CAB International, Southeast Asia Regional Centre, pp. $36-41$

Tran, D. H., M. Takagi and K. Takasu 2004 Effects of selective insecticides on host searching and oviposition behavior of Neochrysocharis formosa (Westwood) (Hymenoptera: Eulophidae), a parasitoid of the American serpentine leafminer. Appl. Entomol. Zool., 39(3): 435-441

Waterhouse, D. F., K. R. Norris 1987 Liriomyza species (Diptera: Agromyzidae) leafminers. In "Biological control: Pacific prospect", ed. by D. F. Waterhouse and K. R. Norris, Inkata Press, Melbourne, Australia, pp. 159-176 